\title{
Technology of rail replacement at end stresses
}

\author{
Sergey Kosenko ${ }^{1, *}$, Sergey Akimov ${ }^{1}$, and Pavel Surovin ${ }^{1}$ \\ ${ }^{1}$ Siberian Transport University, 630049 Novosibirsk, Russia
}

\begin{abstract}
The paper focuses on topical issues relating to the maintenance of buffer spans and temporarily repaired sections of continuous welded rail (CWR) tracks. The paper is aimed at developing and studying the feasibility of a technology for replacing temperature-stressed continuous welded rails. For the purposes of this research, the analytical modeling method is used. A design model for moving the end of the stressed rail to the side is presented. Equations of deflections and bending moments arising when the rail is bent to the rated value were derived. Stresses on the rail bending length were determined and compared with the maximum allowable ones. A resource-saving technology has been developed for replacing temperature-stressed buffer rails of a CWR track using intermediate rail fastening Vossloh W-30.
\end{abstract}

\section{Introduction}

Due to operational advantages of continuous welded rail (CWR) tracks over jointed tracks, increasingly more CWR tracks are laid both on Russian railways and railways of other countries $[1,2]$. At present, the total length of CWR tracks in the world has reached 500 thousand $\mathrm{km}$, making up 1/3 of the total length of railway lines [3]. Despite the fact that this track is called "continuous", its design provides for joints with gaps. Gaps are necessary in buffer spans to compensate temperature strains of continuously welded rails.

Buffer spans are the weakest points in CWR tracks [4]. In conditions with a large annual temperature range, which is typical of many regions in the Russian Federation, buffer rails need to be replaced twice a year as part of seasonal maintenance [5]. A rise in temperatures in the spring season leads to the development of longitudinal compressive forces in continuously welded rails and their displacement [6]. Joint gaps in buffer spans are closed, and an end stress between rails arises [7], which makes it much more difficult to replace these rails for short ones.

There are several known technologies for replacing stressed rails. According to the existing technology [8], it is forbidden to change a stressed rail without cutting out its part with flame cutting. In this case, however, rails become unfit for relaying with initial parameters. There are also other ways to remove stressed buffer rails from the track. For example, the end stress of rails can be eliminated by nitrogen cooling of the CWR section adjacent to the buffer rail [9]. Another way of eliminating the end stress is to increase the length of the CWR section adjacent to the buffer rail by creating bending deflection [7].

*Corresponding author: kosenko.s.a@mail.ru 
These methods are quite complex and cannot provide a sufficient level of occupational safety.

The paper is aimed at developing and studying the feasibility of a technology for replacing temperature-stressed continuous welded rails. The novelty of this research is the proposed technology of replacing stressed rails using a hydraulic rail replacement device, supported by equations of deflections and bending moments to move the rail to the rated value.

\section{Research method}

In order to ensure that a removed stressed rail preserves the initial parameters and can be reused many times, a hydraulic rail replacement device is proposed [10] (Fig. 1). The device is designed to replace stressed buffer rails and temporarily repaired sections of CWR tracks.

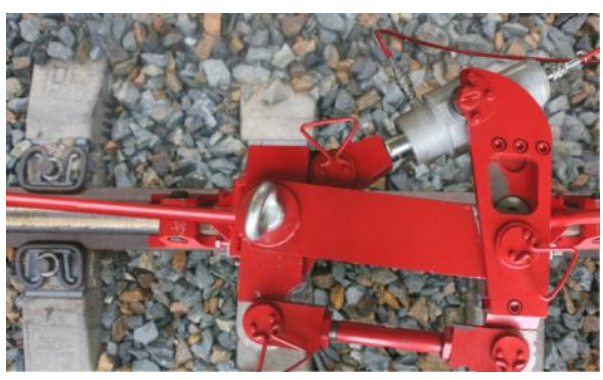

a

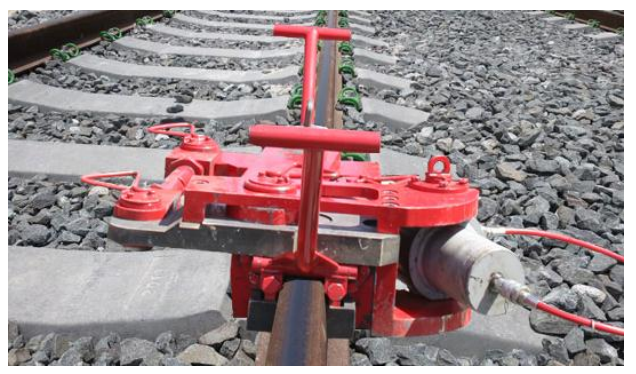

b

Fig. 1. The hydraulic rail replacement device with intermediate rail fastening: a - ZhBR-65Sh; b Vossloh W-30.

In order to justify the feasibility of this device, it is necessary to derive equations of deflections and bending moments arising when the rail is bent to the rated value with the hydraulic rail replacement device. Then the stresses arising in the rail should be determined and compared with the maximum allowable ones. The required equations can be derived through analytical modeling.

In a design model, the rail is considered as a beam with a constant cross-section. The bending axis of the beam can be described by the following differential equation:

$$
E J_{z} \frac{d^{4} v}{d x^{4}}=0
$$

where $E$ is the elastic modulus of the rail steel, $\mathrm{Pa} ; J_{z}$ is the moment of inertia of the rail relative to the vertical axis, $\mathrm{m}^{4}$.

When moving the end of the stressed rail to the side, the rail is exposed to a force $P$ generated by the hydraulic device. The force $P$, located at an angle $\alpha$ to the rail axis, can be decomposed into two components:

$$
\begin{aligned}
& N=-P \cos \alpha ; \\
& Q=-P \sin \alpha,
\end{aligned}
$$


where $N$ is the compressive longitudinal force, $\mathrm{N} ; Q$ is the transverse force in the end section.

In this case, the rail will be subject to bending, and the differential equation of the bending axis can be written as:

$$
E J_{z} \frac{d^{4} v}{d x^{4}}+P \cos \alpha \frac{d^{2} v}{d x^{2}}=0
$$

The design model is shown in Figure 2.

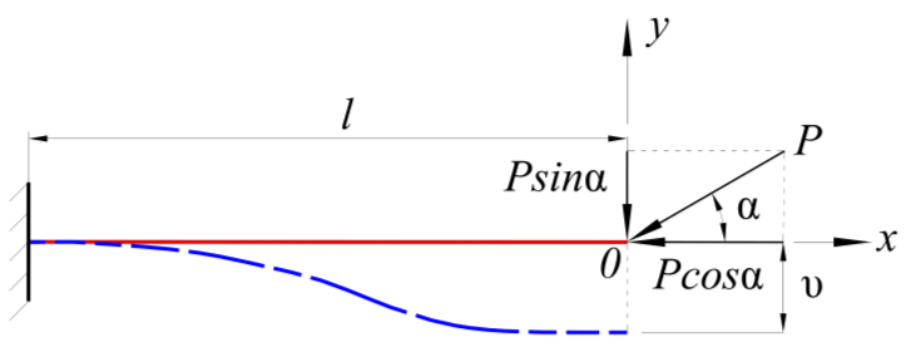

Fig. 2. The design model corresponding to the general solution of the differential equation that describes the bending axis of the beam.

Let us introduce a dimensionless coordinate $\xi=\frac{x}{l}$ and deflection $\mu=\frac{v}{b}$. Here, $l$ is the length of a released section, $\mathrm{m} ; b$ is the value of lateral shifting of a rail, $\mathrm{m}$.

Let us find derivatives of the dimensionless coordinate $\xi$ :

$$
\begin{gathered}
\frac{d v}{d x}=b \frac{d \mu}{d x}=b \frac{d \mu}{d \xi} \frac{d \xi}{d x}=\frac{b}{l} \frac{d \mu}{d \xi} ; \frac{d^{2} v}{d x^{2}}=b \frac{d^{2} \mu}{d x^{2}}=b \frac{d^{2} \mu}{d \xi^{2}} \frac{d^{2} \xi}{d x^{2}}=\frac{b}{l^{2}} \frac{d^{2} \mu}{d \xi^{2}} \\
\frac{d^{3} v}{d x^{3}}=b \frac{d^{3} \mu}{d x^{3}}=b \frac{d^{3} \mu}{d \xi^{3}} \frac{d^{3} \xi}{d x^{3}}=\frac{b}{l^{3}} \frac{d^{3} \mu}{d \xi^{3}} ; \frac{d^{4} v}{d x^{4}}=b \frac{d^{4} \mu}{d x^{4}}=b \frac{d^{4} \mu}{d \xi^{4}} \frac{d^{4} \xi}{d x^{4}}=\frac{b}{l^{4}} \frac{d^{4} \mu}{d \xi^{4}}
\end{gathered}
$$

Then the equation (4) can be rewritten as:

$$
E J_{z} \frac{b}{l^{4}} \frac{d^{4} \mu}{d \xi^{4}}+P \cos \alpha \frac{b}{l^{2}} \frac{d^{2} \mu}{d \xi^{2}}=0 .
$$

By multiplying the derived equation by $\frac{l^{4}}{E J_{z} b}$, we will obtain:

$$
\frac{d^{4} \mu}{d \xi^{4}}+\frac{P l^{2} \cos \alpha}{E J_{z}} \frac{d^{2} \mu}{d \xi^{2}}=0
$$

Let us introduce a dimensionless coefficient $n^{2}=\frac{P l^{2} \cos \alpha}{E J_{z}}$.

The general solution of this equation is a function

$$
\mu(\xi)=C_{1}+C_{2} \xi+C_{3} \cos n \xi+C_{4} \sin n \xi .
$$


When the end of the stressed rail is moved to the side with the hydraulic rail replacement device, there is no contact between the rails at the joint and the end section of the rail cannot be turned. In this case, the boundary conditions can be defined as:

$$
v(l)=0, \quad v^{\prime}(l)=0, \quad v(0)=b, v^{\prime}(0)=0
$$

or in dimensionless form

$$
\mu(1)=0, \mu^{\prime}(1)=0, \mu(0)=1, \mu^{\prime}(0)=0 .
$$

System of boundary conditions:

$$
\begin{gathered}
\mu(1)=C_{1}+C_{2}+C_{3} \cos n+C_{4} \sin n=0 ; \mu^{\prime}(1)=C_{2}-C_{3} n \sin n+C_{4} n \cos n=0 ; \\
\mu(0)=C_{1}+C_{2} \cdot 0+C_{3} \cos 0+C_{4} \sin 0=1 ; \mu^{\prime}(0)=C_{2}-C_{3} n \sin 0+C_{4} n \cos 0=0 .
\end{gathered}
$$

Under these boundary conditions, we obtain the following system of equations:

$$
\begin{gathered}
C_{1}+C_{2}+C_{3} \cos n+C_{4} \sin n=0 ; \\
C_{2}-C_{3} n \sin n+C_{4} n \cos n=0 ; \\
C_{1}+C_{3}=1 ; C_{2}+C_{4} n=0 .
\end{gathered}
$$

After intermediate calculations and transformations, the constants of the equations can be determined as follows:

$$
\begin{gathered}
C_{1}=\frac{\cos n(\cos n-1)+\sin n(\sin n-n)}{(\cos n-1)^{2}+\sin n(\sin n-n)} ; C_{2}=\frac{n \sin n}{(\cos n-1)^{2}+\sin n(\sin n-n)} ; \\
C_{3}=\frac{1-\cos n}{(\cos n-1)^{2}+\sin n(\sin n-n)} ; C_{4}=\frac{-\sin n}{(\cos n-1)^{2}+\sin n(\sin n-n)}
\end{gathered}
$$

Then the expression for deflections will look like this:

$$
\mu(\xi)=\frac{\cos n(\cos n-1)+\sin n(\sin n-n)+(n \sin n) \xi+(1-\cos n) \cos n \xi-\sin n \sin n \xi}{(\cos n-1)^{2}+\sin n(\sin n-n)}
$$

Let us write the second derivative

$$
\mu^{\prime \prime}(\xi)=-n^{2} \frac{(1-\cos n) \cos n \xi-\sin n \sin n \xi}{(\cos n-1)^{2}+\sin n(\sin n-n)}
$$

The equation of the bending moment will look like this:

$$
\begin{aligned}
& M=-E J_{z} \frac{b}{l^{2}} \mu^{\prime \prime}(\xi)=-\frac{E J_{z} b}{l^{2}} n^{2} \frac{-(1-\cos n) \cos n \xi-\sin n \sin n \xi}{(\cos n-1)^{2}+\sin n(\sin n-n)}= \\
& =P b \cos \alpha \frac{(1-\cos n) \cos n \xi-\sin n \sin n \xi}{(\cos n-1)^{2}+\sin n(\sin n-n)}
\end{aligned}
$$

The stresses arising in the buffer rail when one of its ends is moved to the rated value with the hydraulic rail replacement device are determined by the formula:

$$
\sigma=\frac{N}{A}+\frac{M}{J_{z}} y
$$

where $A$ is the cross-sectional area of the rail, equal to $82.65 \mathrm{~cm}^{2}, J_{z}=564 \mathrm{~cm}^{4}, y$ is the distance to the furthest point. 


\section{Results}

Based on the derived equations of deflections and bending moments, stresses in different sections of the rail were determined. Their values are given in Table 1.

Table 1. Stresses arising in sections when one of ends of a stressed rail is released.

\begin{tabular}{|l|c|c|c|c|c|c|c|}
\hline \multirow{2}{*}{ Parameter } & \multicolumn{7}{|c|}{ Distance from the end, m: } \\
\cline { 2 - 8 } & 0 & 1 & 2 & 3 & 4 & 5 & 6 \\
\hline Deflection, $\mathrm{m}$ & 0.16 & 0.15 & 0.12 & 0.08 & 0.04 & 0.01 & 0.00 \\
\hline $\begin{array}{l}\text { Bending moment, } \\
\mathrm{kN} \cdot \mathrm{m}\end{array}$ & -4.67 & -5.05 & -3.23 & 0.00 & -3.23 & -5.05 & -4.67 \\
\hline Stress, MPa & -62.17 & -67.16 & -42.95 & -0.06 & -42.95 & -67.16 & -62.17 \\
\hline
\end{tabular}

The maximum edge stresses arising in sections during the release of the stressed rail reach $67.16 \mathrm{MPa}$. They do not exceed the maximum allowable edge tensile stresses in the rail foot $(240 \mathrm{MPa})$. Therefore, plastic deformations will not occur in the rail if the length of its bending part will be $6 \mathrm{~m}$. The hydraulic rail replacement device can be used to replace temperature-stressed rails of CWR tracks.

The Department of Track and Track Facilities, Siberian Transport University, in collaboration with the Road Design and Engineering Office of the West Siberian Railway, developed a buffer rail replacement process for CWR tracks using KB-65 separate clip-bolt fastenings with plates, and then launched this process into production. A patent [11] was obtained. The features of this operating procedure are detailed in [12].

Over the past years, track sections with KB-65 fastenings throughout Russia have been replaced for fastenings that have a small number of elements and are less metal-intensive. These include Russian products - ZhBR fastenings of various modifications (for reinforced concrete sleepers) and APC-4 (anchor-type fastenings), as well as imported fastenings - $W$ 30 (Vossloh) and P-350 (Pandrol).

Screw-dowel rail fastenings without plates, ZhBR-65Sh and Vossloh W-30, are of particular interest. These types of fastenings are promising: they ensure smooth movement and effective interaction of rolling stock with track superstructures.

In this connection, a technological process and a process chart were developed to replace temperature-stressed rails with screw-dowel fastenings ( $W-30$ and ZhBR-65Sh). A schedule for replacement of stressed buffer rails with $W-30$ fastenings (Vossloh) is presented in Figure 3.

The work is carried out by a track repair team of eight members [13].

Prior to closing the relevant section for train traffic and beginning the replacement of buffer rails, preparatory steps should be taken: pulling screws of rail fastenings in anchoring sections (50 $\mathrm{m}$ away from the rail to be replaced in both directions) [9]; loosening and removal of four fish bolts (second and fifth ones) at two joints.

After the completion of the preparatory steps listed above, the relevant section is closed for train traffic. The work area is fenced in accordance with [14].

W-30 rail fastenings are dismantled from joint sleepers. The rail is lifted with a hydraulic jack. A pad is removed from the rail foot on the joint sleeper, which is on the side of the buffer rail.

The next steps are dismantling the rail joint and assembling the hydraulic rail replacement device. The device is activated. Pressure is created in the hydraulic system of the device. This transfers a separating force to wedge clamps. In this state, the hydraulic device functions as a joint plate. This prevents the rail from being released and ensures safety at work. 
Then fastening elements are removed from the temperature-stressed buffer rail at 10 sleeper ends on the side of the hydraulic rail replacement device (on the inner side). On the outside of the rail, elastic clips are moved to the mounting position [15]. In this case, the length of the released rail will be 6 meters, which corresponds to the design model (Fig. 2) for determining edge stresses in the rail foot.

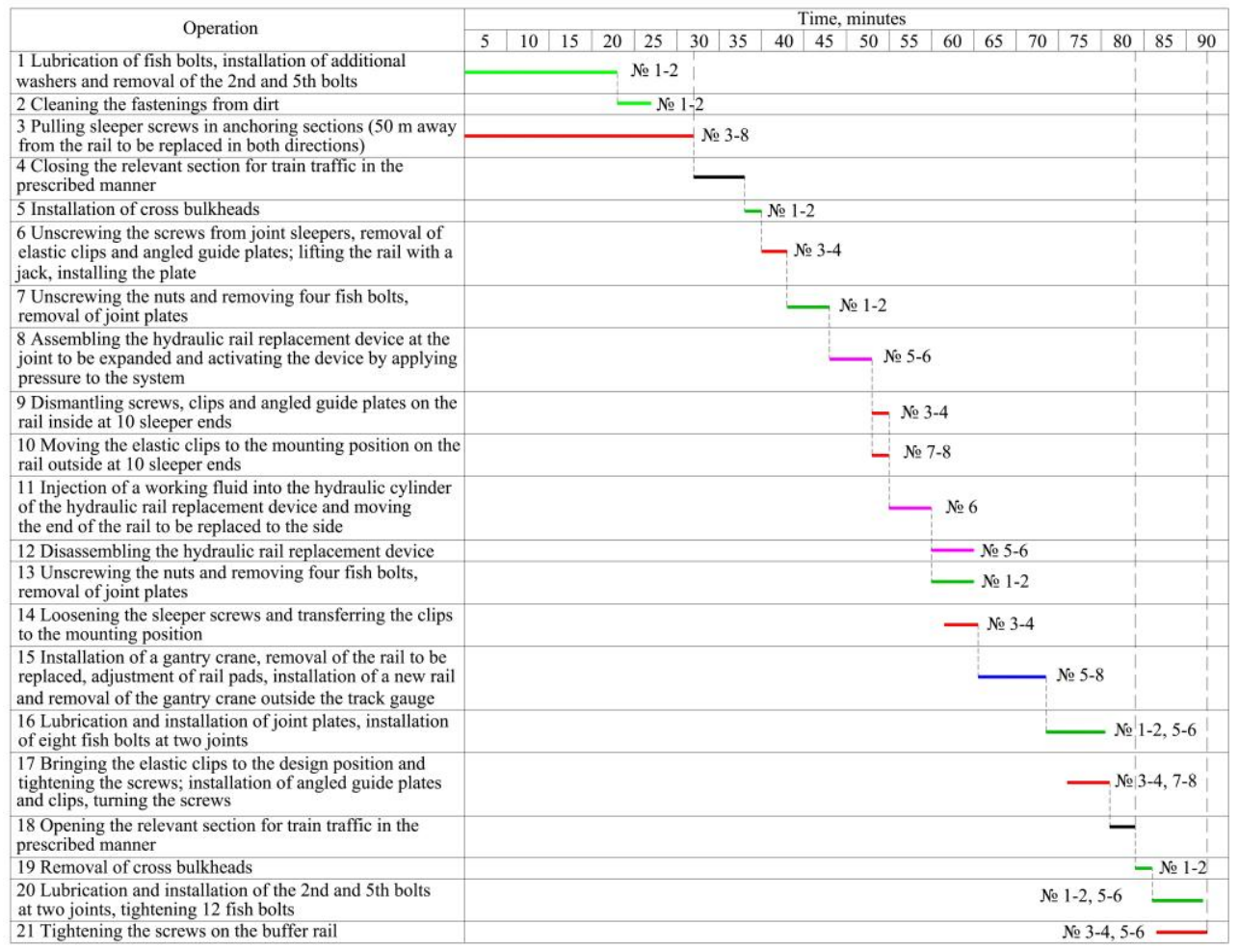

Fig. 3. A schedule for replacement of stressed buffer rails with the $W-30$ (Vossloh) screw=dowel rail fastening without plates.

After releasing a part of the rail from connections with the base, the end of the stressed rail can be moved to the side using the hydraulic rail replacement device. The end of the buffer rail is moved to the side up to the width of the rail foot and a small gap to ensure free longitudinal rail movement. In this case, the deformed axis of the bending part of the buffer rail will correspond to the design model (Fig. 2). Values of deflection are given in Table 1. Wedge clamps of the device are wedged. The hydraulic rail replacement device is disassembled.

Simultaneously with the removal of the hydraulic device, the joint plates on the second joint are dismantled. The elastic clips of the fastenings on the stressed part of the rail are moved to the mounting position [15].

Then the rail is replaced. A gantry crane is used to remove an old rail and install a new one [13].

After laying a new buffer rail of a shorter length, joint plates with four bolts at each joint are installed on both rail joints. Intermediate fastenings are installed along the entire length of the rail. Then track is opened for train traffic in the prescribed manner. 
At the final stage, the remaining four bolts are installed. Nuts of all 12 fish bolts are tightened. In addition, the sleeper screws are tightened along the entire length of the buffer rail.

The total duration of on-track operations that require the section to be closed for train traffic is 55 minutes.

\section{Conclusion}

Using the derived equations of deflections and bending moments, as well as calculated edge stresses at the rail foot arising from its bending with the hydraulic rail replacement device, the feasibility of the proposed technology for replacing temperature-stressed continuous welded rails was justified. The developed technology will allow rails to be replaced without flame cutting. In this case, rails can be reused many times after seasonal replacements. The research results will contribute to timely maintenance of buffer spans and resource saving by increasing the life cycle of the basic element of track superstructures - the rail. The practical value of the proposed technology is that it ensures the safety and mechanization of work.

The technologies developed for KB-65, ZhBR-65Sh and Vossloh $W-30$ are applicable to $70 \%$ of the total length of continuous welded rail tracks in Russia. The proposed technologies are also applicable to railways of other countries that use similar fastenings. Further research may be aimed at improving the technology for replacing stressed rails for the considered and other types of intermediate fastenings. This will improve safety and reduce the time of maintenance.

\section{References}

1. P. Wang , K. Xie, L. Shao, L. Yan, J. Xu, R. Chen, Smart Materials and Structures, 25, 015019 (2016).

2. H.-U. Bae, J.-Y. Choi, J. Moon, N.-H. Lim, Journal of Rail and Rapid Transit, 230, 747-758 (2016).

3. P. Wang, K. Xie, R. Chen, L. Shao, L. Yan, H. Liu, M. Zhang, Journal of Sensors, 2016, 3917604 (2016).

4. V.M. Ermakov, M.A. Egorov, Railway Track and Facilities, 9, 25-29 (2015). (in Russian)

5. V.I. Novakovich, Railway Track and Facilities, 11, 2-4 (2008). (in Russian)

6. N.Ö. Bezgin, $4^{\text {th }}$ International Conference on Welding Technologies and Exhibition (Gaziantep, Turkey, 2016).

7. G.G. Zhulev, RU Patent 2045601 (1995). (in Russian)

8. Instrukcija po ustrojstvu, ukladke, soderzhaniju i remontu besstykovogo puti [Instructions for the installation, laying, maintenance and repair of a continuous welded path], of 14.12.16 No. 2544/p (Moscow, 2016). (in Russian)

9. G.G. Zhulev, RU Patent 2064027 (1996). (in Russian)

10. S.A. Kosenko, R.V. Shangin, A.S. Shurugin, S.S. Akimov, Modern Technologies. System Analysis. Modeling, 3(47), 187-190, (2015). (in Russian)

11. A.S. Shurugin, R.V. Shangin, S.A. Kosenko, S.S. Akimov, N.N. Starovoyt, RU Patent 2643324 (2018). (in Russian)

12. S.A. Kosenko, A.S. Shurugin, O.G. Yudin, S.S. Akimov, Transport of the Urals, 2(49), 44-47 (2016). (in Russian) 
13. Tehnicheski obosnovannye normy vremeni na raboty po tekushhemu soderzhaniju puti [Technically justified time limits for work on the current track content], of 30.03.2009 (ed. 2015). (in Russian)

14. Instrukcija po obespecheniju bezopasnosti dvizhenija poezdov pri proizvodstve putevyh rabot [Instructions for ensuring the safety of train traffic in the manufacture of track works], of 14.12.16, No. 2540/p (Moscow, 2016). (in Russian)

15. Instrukcija na sborku, ukladku i jekspluataciju puti s promezhutochnym rel'sovym skrepleniem tipa W 30 na zhelezobetonnyh shpalah [Instruction for assembly, laying and operation of a track with an intermediate rail fastener type $\mathrm{W} 30$ on reinforced concrete sleepers], of 31.01.2014, No. 225p (Moscow, 2014). (in Russian) 